\title{
MOTIVATIONAL CONTENT ANALYSIS OF PRIMARY SCHOOL TEXTBOOKS ON LITERATURE IN CONTEXT OF D. MCCLELLAND'S THEORY
}

\section{E. V. Bataeva}

Kharkov Humanitarian University "People Ukrainian Academy", Kharkov, Ukraine. E-mail: bataevaekaterina72@yahoo.com

Abstract. Introduction. The main motives of human behavior are formed at the primary school age. Several factors play a determining role in children's development: up-bringing in the family, style of teaching at school, quality of popular literature and other sources of information, and, in particular, school textbooks. The special importance is given to the content quality of school textbooks. The influence of school textbooks is determined by the fact that school children should necessarily get familiar with the printed materials, resulting, as a consequence, in accepting the patterns of social interaction and motive-codes introduced there. Due to high constructivist potential of school textbooks, it seems necessary to carry out content analysis of textbooks' for the purpose of identifying the influence on certain motive trends formation in schoolchildren.

The aim of the publication is to present the methodology of motivational analysis of school textbooks on literature and the results of its approbation when studying the motivational content of Ukrainian textbooks for primary school.

Methodology and research methods. The research methodology is based on comparative, socio-constructivist, sociocultural and system-activity approaches to implementation of educational process and preparation of didactic materials. Scientific methods involve: analysis and synthesis of the content of sociological, socio-psychological, pedagogical and methodical literature; content analysis of educational texts.

Results and scientific novelty. The author's methodology of motivational content analysis of primary school textbooks on literature developed in the context of D. McClelland's theory is described. As the main categories of motivational content analysis of texts, the motives of behavior introduced by D. McClelland (achievements, affiliation, positive and negative power, avoidance of failure) as well as the motives of self-expression and refusal of affiliation have been used. As a result of the analysis of Ukrainian textbooks on literature for the $2^{\text {nd }}-5^{\text {th }}$ forms, it has been revealed that the affiliation motive occurred to be the dominant one, which has a positive motivational tendency. Among negative motivational tenden- 
cies have been discovered: low level of representation of motives of achievement and self-expression; a relatively high frequency of using negative motive of power (numerous examples of manipulating people for own self-affirmation, authoritarianism of literature characters, use weakness of subordinates, etc.) and the motive of failure avoidance (the person's inability/unwillingness to work hard self-removal under difficulties). It has been concluded that high level of negative motives in primary school textbooks could indirectly influence the formation of passive life attitudes of primary school children.

Practical significance. The proposed author's methodology might be useful for the organization of comparative intercountry studies on identification of specific differences in training of children in different countries. The results of the research could also serve as one of the strongest justifications for the need to update and reform the system of elementary school education.

Keywords: motive of behavior, achievement, affiliation, power, avoidance of failure, self-expression, refusal of affiliation, content analysis, literature textbook, primary school.

Acknowledgements. The author expresses her sincere gratitude to all the reviewers for a very thoughtful critical analysis, which helped the author to significantly improve the article.

For citation: Bataeva E. V. Motivational content analysis of primary school textbooks on literature in context of D. McClelland's theory. The Education and Science Journal. 2018; 1 (20): 136-151. DOI: 10.17853/1994-5639-2018-1-136-151

\section{МОТИВАЦИОННЫЙ КОНТЕНТ-АНАЛИЗ УЧЕБНИКОВ ПО ЛИТЕРАТУРЕ ДЛЯ НАЧАЛЬНОЙ ШКОЛЫ В КОНТЕКСТЕ ТЕОРИИ Д. МАККЛЕЛЛАНДА}

\section{Е. В. Батаева}

Харьковский гуманитарный университет "Народная украинская академия", Харьков, Украина.

E-mail: bataevaekaterina72@yahoo.com

Аннотаиия. Введение. Ведущие мотивы деятельности и поведения чемовека складываются в возрасте, совпадающем со временем обучения в начальной школе. Определяющую роль в их развитии играют несколько факторов: воспитание в семье, характер обучения в образовательном учреждении, качество предлагающейся ребенку популярной митературы и других информационно-познавательных источников - прежде всего школьных учебников. Особая значимость качественного наполнения учебников состоит в том, что дети в обязательном порядке знакомятся с размещенными в них материала-

Образование и наука. Том 20, № 1. 2018/The Education and Science Journal. Vol. 20, № 1. 2018 
ми, в результате чего так или иначе усваивают транслируемые в учебных текстах модели социального взаимодействия. Высокий конструктивистский потенциал учебников свидетельствует о целесообразности и необходимости всестороннего исследования влияния их содержания на формирование мотивационных новообразований у обучающихся.

Цель публикации - представить методику анализа мотивационной направценности школьных учебников по митературе и итоги апробации данного инструментария при изучении содержания украинских учебников дмя начальных классов.

Методология и методы. Работа осуществцялась с опорой на положения сравнительного, социально-конструктивистского, социокультурного и системно-деятельностного подходов к осуществлению учебно-воспитательного процесса и подготовке дидактических материалов. Использовались такие научные методы, как анализ и обобщение содержания социологической, социально-психологической, педагогической и методической митературы; контентанализ учебных текстов.

Результаты и научная новизна. Описана разработанная автором методика мотивационного контент-анализа школьных учебников, основу которой составили постулаты теории Д. МакКлемланда. В качестве ключевых категорий, определяющих качество мотивационного содержания учебных текстов, были избраны выделенные выдающимся психологом в методике оценки мотивации показатели достижения, аффилиации (причастности), положительной и негативной вмасти, избегания неудачи, дополненные мотивами самовыражения и отказа от аффилиации. Предпринятый контент-анализ украинских учебников по митературе дмя 2-5-го классов показал, что базовым позитивным мотивом, который чаще всего воспроизводится в дискурсивном пространстве учебной митературы, является аффициация. Среди негативных мотивов-тенденций отмечены слабая ориентация на достижение поставменных цемей и самореализацию; частое присутствие негативного мотива вмасти (многочисленность примеров манипулирования моутверждения, а также примеров авторитарности митературных героев, испоцьзования ими в своих интересах слабости других и т. п.) и мотива избегания неудачи (самоустранения при столкновении с трудностями). Сделан вывод о том, что высокая степень культивирования негативных мотивов поведения в школьных учебниках может стать косвенной причиной формирования пассивных жизненных установок детей миадшего школьного возраста.

Практическая значимость. Предлагаемая авторская методика будет полезна при организации кросс-культурных сравнительных исследований по выявлению специфических отмичий в обучении детей в разных странах. Результаты исследования могут также служить одним из убедительных обоснований необходимости коррекции и реформирования системы обучения в начальной школе.

Образование и наука. Том 20, № 1. 2018/The Education and Science Journal. Vol. 20, № 1. 2018 
Ключевые слова: мотив поведения, достижение, аффимиация, вмасть, избегание неудачи, самовыражение, отказ от аффилиации, контент-анализ, учебник по митературе, начальная школа.

Благодарности. Автор выражает признательность рецензентам за глубокий критический анализ текста статьи, позволивший значительно улучшить ее качество.

Для иитирования: Bataeva E. V. Motivational content analysis of primary school textbooks on literature in context of D. McClelland's theory // Обpaзование и наука. 2018. Т. 20, № 1. C. 136-151. DOI: 10.17853/1994-56392018-1-136-151

\section{Introduction}

According to D. McClelland (1917-1998), the main motives of human behavior (achievement, affiliation, power and avoidance of failure) are formed in childhood (the optimal period is from 6 to 10 years, that is, during the primary school) when several factors play a determining role in children's development: up-bringing in the family, style of teaching at school, as well as the content of popular literature, folklore (tales, myths, legends) and school textbooks. The influence of the latter is determined by the fact that school children should necessarily get familiar with such texts, resulting, as a consequence, in accepting the patterns of social interaction and motive-codes introduced there. Frequency of motive situations (that is, the sense contexts in which a certain behavioral motive is presented) in texts plays a great role in motive formation. Hence, D. McClelland considered it necessary to use the method of content analysis of children's literature and school textbooks for identifying the basic motives of behavior. "Content analysis is a technique for examining the content or information and symbols contained in written documents or other communication media (e.g., photographs, movies, song lyrics, advertisements)" [1, p. 49].

D. McClelland considers that school literature has a significant influence on what motivations of behavior would be basic (typical, common) in a society. At the same time, textbooks are produced by representatives of a particular society who are "bearers" of motive-codes typical for this society. Therefore, the textbooks can reflect the dominant motivational tendencies typical for the population of a country. D. McClelland supposes that "in most countries educational authorities take great care to make sure that children read in school what is considered right and proper. What educational authorities think is right for children to read may well represent the motivational ideas 
uppermost in the minds of people in a country" [2, p. 432]. The importance of studying the motive content of primary school textbooks is determined not only by their constructivist but also by predictive potential: depending on what motivations are "cultivated" in school literature, how much attention is given to motivation of achievement (which directly relates to life and professional success of an individual), we can draw conclusions about how achievable and successful can become representatives of older age groups (who have been "trained" by these textbooks). Due to high constructivist potential of school textbooks on literature for primary school (where the motives are presented in an artistic form that facilitates their perception by children and subsequent internalization), it seems necessary to carry out motivational content analysis of Ukrainian literature textbooks for the purpose of identifying certain motive trends. Although there are different concepts of motivation (for example, Maslow's Hierarchy of Needs, Two-Factor Theory of F. Herzberg, B. Weiner's Three-Dimensional theory of attribution, etc.), we use McClelland's methodology. This is firstly explained by the opportunity of operationalization of its main categories that can be presented by means of concrete indicators. Secondly, the universality of these categories can be applied to both children and adult literature, both real and imaginary contexts. According to the results of content analysis, it will be possible to make assumptions about what motivations of behavior can be formed in primary school in Ukraine and what motives of behavior can become dominant in Ukrainian society in the future.

\section{Literature Review}

In the modern theory of education, the problem of school influence on the changing the values and motivational patterns in different societies, the topic of transferring values through school textbooks, is actively discussed. As demonstrated by Bowles S. and Gintis H. in "Schooling in Capitalist America", there is a correspondence between schooling and the social-class and economic system; the school transfers and consolidates certain values, motivational patterns, cognitive skills that contribute to the reproduction of a certain type of social relations [3]. Modern researchers pay special attention to studying the influence of gender and professional stereotypes, verbalized or visualized in school textbooks, on the process of forming the social identity of schoolchildren, often using the content analysis method [4-9].

The theory of achievement motivation is often used in education study to explore the impact of teachers' motivational techniques on students' academic achievements $[10$, p. $15 ; 11$, p. 217]; to analyze the impact of intrinsic 
and extrinsic motivation on students' different engagement types [12, p. 252]; to investigate the relation between social position in class and achievement motivation [13, p. 61]. The Russian researcher L. Okolskaya conducted a content analysis of Soviet and modern Russian school textbooks using McClelland's theory; the motive of achievement was operationalized through five indicators: the difficulty of labor for a literature character, the connection of work with danger or risk, the limited time to commit the work, the proposal of innovative solutions by a literature personage [14, p. 78]. Content analysis of school textbooks using D. McClelland's theory has also been done by Iranian researcher N. Shahmohammadi who paid the particular attention to studying the achievement motive in Iranian textbooks of primary school. In his analysis, N. Shahmohammadi used the following ten components of achievement motive: "high level of wish; strong motive for moving up; long-term preservation and endurance in facing assignments with mid-range difficulty level; interest for doing the halted work; possessing a dynamic understanding of time and realizing that matters happen quickly; having understanding of the future; doing a task in the right way; paying attention to the basis for selecting a friend, colleague, and a model; re-understanding through good activity at work; behavior that consists of taking low amount of risk" [15, p. 429].

In our study, we consider five motives of behavior presented in literature textbooks (achievement, affiliation, power, avoidance, self-expression); methodology of analysis is given below. To the best of our knowledge, the motiveanalysis of school textbooks in Ukrainian literature (for the $2^{\text {nd }}-5^{\text {th }}$ forms) [1619] using the theory of human motivation by D. McClelland is carried out for the first time.

The aim of this paper is to develop a methodology for motivational content analysis of school textbooks on literature, to conduct a motivational content analysis of Ukrainian textbooks on literature for primary school and identify trends in their motivational content.

\section{Methodology of motivational content analysis of school textbooks}

The purpose of motivational content analysis is to study frequency in the text (verbal or visual) of various motive situations, i.e. semantic fragments of the text in which a certain behavioral motive is "played out". Motive is "a recurrent concern for a goal state or condition as measured in fantasy, which drives, directs and selects the behavior of the individual" [2]). The volume of these fragments can vary from one phrase to several paragraphs in which a certain behavioral situation develops dynamically. 
As the main categories of motivation content analysis of educational texts, we will use, firstly, the motives of behavior introduced by D. McClelland (achievement, affiliation, positive and negative power and avoidance) and, secondly, a motive that, in our view, should be added to the list of D. McClelland, namely, the motive of self-expression. If the motive of achievement described by D. McClelland is more closely related to values of industrial society, the motive of self-expression is a part of value pattern of post-industrial society [20, p. 12]: "in postindustrial societies in recent decades, rising emphasis on self-expression values has become the key cultural manifestation of modernization. Human choice and emancipation have become the leading themes in all domains of life from politics to child care to gender relations to work motivations to religious orientations and civic engagement" [21, p. 47]. Let us analyze each of these categories of motivational content analysis and determine the units of analysis.

1. Motive of achievement. Empirical indicators of this category are the following:

1) person's continuous work on a task until it is solved;

2) desire of a person to constantly improve a process and results of his/her activities;

3) intention to transcend existing standards in the field of specific activities;

4) willingness to take responsibility for any results of activities on himself/herself ("people high in the need for Achievement tend to seek out and do better at moderately challenging tasks, take personal responsibility for their performance, seek performance feedback on how well they are doing, and try new and more efficient ways of doing things" [2, p. 251]).

Since the motivational content analysis is aimed at studying the frequency of appearance of certain behavioral situations in the text, both verbal and semantic (situational) indicators have been selected as units of analysis. The semantic units of analysis, correlated with the category of achievement, are the motive-situations of hard work for performing certain tasks; the dedication of literature characters who, due to their own efforts, achieve certain results; completion of the begun work; willingness to be responsible for its results; independence in the realization of certain tasks. The verbal units of analysis correlated with the semantic indicators are the words that indicate activity aimed at achieving a certain result ("to do, to finish, to plan, to put the task, to complete, to do homework, to dig up a garden", etc.); positive evaluations of the work performed by a literature personage ("well/quickly/masterfully did, surpassed others, showed the best result", etc.). 
2. The motive of power. D. McClelland distinguished two modifications of this analytic category - positive and negative motives of power. The positive motive of power is manifested in the following empirical indicators:

1 ) in the aspiration of a person to power, because it allows a faster solution of certain tasks as a result of obtaining additional managerial resources;

2) in the care of a person about the well-being of subordinates;

3) in an effort to create optimal conditions for successful solving of collective problems.

The semantic units of analysis of educational texts, correlated with the positive motive of power, are the motive-situations of protection of subordinates by a person possessing power (king, prince, commander); respect and love of subordinates to a person who governs them; making fair decisions about controversial issues by a person endowed with power. Verbal indicators of the positive motive of power are the words corresponding to semantic units of analysis (positive epithets used in relation to a personage with power (for example, "glorious, fair, courageous prince"); words of respect and reverence for such people; words of concern for the rulers of subordinates ("protect, provide with housing/money, help solving certain problems/tasks", etc.).

The negative motive of power is manifested

1) in the desire of a human to manage/manipulate people for his/her own satisfaction and self-affirmation, and not for solving a particular social problem;

2) in ignoring the interests of subordinates;

3) in deliberately causing them harm.

The semantic units of analysis correlated with the negative motive of power are the motive-situations of suppression/humiliation/punishment of other people for satisfying his/her own ambitions, in the authoritarianism of literature characters, who want to strengthen their own power status. Verbal indicators of the negative motive of power are words that correspond to the indicated semantic units of analysis ("attack, drive, threaten, insult, exploit, demonstrate superiority, use weakness of subordinates, beat, kill”, etc.); negative epithets used in relation to the character endowed with power ("evil, nasty, cruel, unjust", etc.), negative evaluations of the actions of the personage ("he/she has spoiled everything, destroyed, deprived life/property", etc.).

3. The motive for affiliation appears itself

1) in the striving of a person to establish and keep positive emotional relations with people;

2) in providing assistance/support to surrounding people; 
3) in the need for approval and in the fear of rejection/criticism from other people.

This motive (however, like all the others) can also manifest itself in texts, the heroes of which are personified animals, plants, mythical characters. The semantic units of analysis of educational texts, correlated with the motive of affiliation, are the motive-situations of mutual assistance, friendship, love, care of a literature personage about other people or about nature. The verbal indicators of affiliation motive are the words describing the search for friendly relations, communication with others, social cooperation, love, joining groups ("to love, rejoice, play, have fun, help, support, present, work together, thank, teach, caress, kiss", etc.); positive assessments of surrounding people ("good, kind, tender, reliable", etc.).

4. In addition to the motivation for affiliation, we have introduced a category into the methodology of motivational content analysis (which D. McClelland did not specifically analyze, but which is often encountered in literature texts) - the motive of refusal of affiliation. The semantic units of analysis, correlated with the motive of refusal of affiliation, are the motive-situations of avoiding friendship or love, unwillingness to help or to take care over surrounding people being in rudeness, aggressiveness, deception. Verbal indicators of the motive of refusal of affiliation are words that correspond to the indicated semantic units of analysis ("refuse of friendship/love, scold, refuse to share with others any good, do not keep promises, deceive", etc.), negative emotions to friends/neighbors/relatives ("to hate, envy, despise, scoff", etc.).

5. The motive of avoidance of failure is opposite to the motive of achievement and is manifested in the following empirical indicators:

1) the person's inability/unwillingness to work hard on the realization of a complex task;

2) shifting responsibility for the results of activities to others;

3) the non-purposefulness of a person who prefers to stop doing something halfway if it seems energy-consuming or boring.

Semantic units of analysis, correlated with the motive of avoidance of failure, are motivational situations of laziness, idleness, lack of initiative, fear of novelty. The verbal indicators of this motive are words that fix negative outcome of events ("error, disaster, defeat, trouble"), fear of starting work ("I would not be able, I can not, I'll waste my energy"), incompleteness of action ("did not finish and abandoned, postponed until later"), negative assessments of the quality of the work performed ("badly made, ruined, caused damage", etc.).

In motivational content analysis one more category which can be regarded as the extreme form of the motive of avoidance of failure is used - this is 
a real failure, which semantic units of analysis are illness, death of a literature character, loss of friends/beloved, defeat in battle, ruin, famine, loss of valuable things, etc.; negative emotions of the personages associated with failure ("sobbed bitterly, sad, wilted his head", etc.).

6. The motive of self-expression (D. McClelland did not analyze it, but it has become especially relevant in the context of post-modernization of values in modern society) is manifested in situations of creative activity that is important by itself and not as a tool of achieving future goals (as in the case of achievement). Semantic units of analysis, correlated with the motive of selfexpression, are the motive-situations of singing, drawing, embroidering, composing verses, theatrical performances, scientific creativity, construction, which bring pleasure, joy and satisfaction with life and do not imply the pursuit of success or gaining life bonuses. Verbal indicators of the self-expression motive are words that correspond to the indicated semantic units of analysis ("sing, read poems, draw, perform, dance", etc.); a positive attitude toward creative process ("she loved singing, he liked drawing", etc.); positive evaluations of creative activity by other people ("how beautifully she sings, skillfully reads poetry", etc.).

\section{The results of motivational content analysis of Ukrainian textbooks on literature}

During the motivational content analysis of four textbooks on Ukrainian literature [8-11] all texts in them were studied: 100 texts $\left(2^{\text {nd }}\right.$ form), 84 texts $\left(3^{\text {rd }}\right.$ form), 91 texts ( $4^{\text {th }}$ form), 47 texts $\left(5^{\text {th }}\right.$ form), totally -222 texts; the total volume is 801 pages; the total number of motive situations was 974 (on the contrary, McClelland's comparative intercountry study used a method of selective text analysis: "in each case, twenty-one stories were selected at random from at least three different readers from the second, third, and fourth grades" [2, p. 432]). The Table below presents the results of the content analysis of textbooks, in which two indicators are used: the number of situations in which a certain motive of behavior is manifested and percentage of these situations with respect to all analyzed motivational contexts.

The first place in the rating of dominant motives of behavior, revealed in all analyzed textbooks, has been taken by the motive of affiliation (on average, $30 \%$ of all motive-situations); the last place has been taken by the motive of self-expression (on average, 3.7\%). Approximately in equal proportions the remaining motives are presented: the motive of avoidance of failure $(18 \%)$, the motive of achievement (16.8\%), the motive of power $(15.6 \%)$ and the motive of refusal of affiliation (15.6\%). 
Results of motivational content analysis of Ukrainian textbooks

\begin{tabular}{|c|c|c|c|c|c|c|c|c|c|}
\hline \multirow[b]{2}{*}{ Form } & \multirow[b]{2}{*}{$\begin{array}{l}\text { Achi- } \\
\text { eve- } \\
\text { ment }\end{array}$} & \multirow{2}{*}{$\begin{array}{l}\text { Self- } \\
\text { ex- } \\
\text { pressi- } \\
\text { on }\end{array}$} & \multicolumn{2}{|c|}{ Power } & \multirow[b]{2}{*}{$\begin{array}{l}\text { Affili- } \\
\text { ation }\end{array}$} & \multirow[b]{2}{*}{$\begin{array}{l}\text { Refusal } \\
\text { of affili- } \\
\text { ation }\end{array}$} & \multicolumn{2}{|c|}{ Avoidance } & \multirow{2}{*}{$\begin{array}{l}\text { Total num- } \\
\text { ber of moti- } \\
\text { ve-situati- } \\
\text { ons }\end{array}$} \\
\hline & & & $\begin{array}{l}\text { Positi- } \\
\text { ve }\end{array}$ & $\begin{array}{c}\text { Negati- } \\
\text { ve }\end{array}$ & & & $\begin{array}{c}\text { Avo- } \\
\text { idance } \\
\text { of failu- } \\
\text { re }\end{array}$ & Failure & \\
\hline \multirow{2}{*}{$2^{\text {nd }}$} & \multirow{2}{*}{$\begin{array}{c}42 \\
18.3 \%\end{array}$} & \multirow{2}{*}{$\begin{array}{c}8 \\
3.5 \%\end{array}$} & $\begin{array}{c}11 \\
4.8 \%\end{array}$ & $\begin{array}{c}19 \\
8.2 \%\end{array}$ & \multirow{2}{*}{$\begin{array}{c}81 \\
35.2 \%\end{array}$} & \multirow{2}{*}{$\begin{array}{c}21 \\
9.1 \%\end{array}$} & $\begin{array}{c}23 \\
10 \%\end{array}$ & $\begin{array}{c}25 \\
10.9 \%\end{array}$ & \multirow{2}{*}{230} \\
\hline & & & \multicolumn{2}{|c|}{$\begin{array}{c}30 \\
13 \%\end{array}$} & & & \multicolumn{2}{|c|}{$\begin{array}{c}48 \\
20.9 \%\end{array}$} & \\
\hline \multirow{2}{*}{$3^{\text {rd }}$} & \multirow{2}{*}{$\begin{array}{c}29 \\
14.3 \%\end{array}$} & \multirow{2}{*}{$\begin{array}{c}8 \\
3.9 \%\end{array}$} & $\begin{array}{c}7 \\
3.4 \%\end{array}$ & $\begin{array}{c}17 \\
8.4 \%\end{array}$ & \multirow{2}{*}{$\begin{array}{c}72 \\
35.5 \%\end{array}$} & \multirow{2}{*}{$\begin{array}{c}38 \\
18.7 \%\end{array}$} & $\begin{array}{c}12 \\
5.9 \%\end{array}$ & $\begin{array}{c}20 \\
9.9 \%\end{array}$ & \multirow{2}{*}{203} \\
\hline & & & \multicolumn{2}{|c|}{$\begin{array}{c}24 \\
11.8 \%\end{array}$} & & & \multicolumn{2}{|c|}{$\begin{array}{c}32 \\
15.8 \%\end{array}$} & \\
\hline \multirow{2}{*}{$4^{\text {th }}$} & \multirow{2}{*}{$\begin{array}{c}38 \\
18.3 \%\end{array}$} & \multirow{2}{*}{$\begin{array}{c}9 \\
4.3 \%\end{array}$} & $\begin{array}{c}9 \\
4.3 \%\end{array}$ & \begin{tabular}{|c|}
2210. \\
$6 \%$
\end{tabular} & \multirow{2}{*}{$\begin{array}{c}50 \\
24 \%\end{array}$} & \multirow{2}{*}{$\begin{array}{c}44 \\
21.2 \%\end{array}$} & $\begin{array}{c}19 \\
9.1 \%\end{array}$ & $\begin{array}{c}17 \\
8.1 \%\end{array}$ & \multirow{2}{*}{208} \\
\hline & & & \multicolumn{2}{|c|}{$\begin{array}{c}31 \\
14.9 \% \\
\end{array}$} & & & \multicolumn{2}{|c|}{$\begin{array}{c}36 \\
17.3 \%\end{array}$} & \\
\hline \multirow{2}{*}{$5^{\text {th }}$} & \multirow{2}{*}{$\begin{array}{c}55 \\
16.5 \%\end{array}$} & \multirow{2}{*}{$\begin{array}{c}11 \\
3.3 \%\end{array}$} & $\begin{array}{c}23 \\
6.9 \%\end{array}$ & $\begin{array}{c}44 \\
13.3 \%\end{array}$ & \multirow{2}{*}{$\begin{array}{c}92 \\
27.6 \%\end{array}$} & \multirow{2}{*}{$\begin{array}{c}49 \\
14.7 \%\end{array}$} & $\begin{array}{c}36 \\
10.8 \%\end{array}$ & $\begin{array}{c}23 \\
6.9 \%\end{array}$ & \multirow{2}{*}{333} \\
\hline & & & $\begin{array}{r}6 \\
20\end{array}$ & $\begin{array}{l}7 \\
2 \%\end{array}$ & & & $\begin{array}{r}5 \\
17 .\end{array}$ & & \\
\hline Tata & 164 & 36 & $\begin{array}{c}50 \\
5.1 \%\end{array}$ & \begin{tabular}{|c|}
102 \\
$10.5 \%$ \\
\end{tabular} & 295 & 152 & $\begin{array}{c}90 \\
9.3 \%\end{array}$ & $\begin{array}{c}85 \\
8.7 \% \\
\end{array}$ & 074 \\
\hline lotal & $16.8 \%$ & $3.7 \%$ & $\begin{array}{r}15 \\
15\end{array}$ & $\begin{array}{l}52 \\
6 \%\end{array}$ & $30.3 \%$ & $15.6 \%$ & $\begin{array}{c}17 \\
18 \\
\end{array}$ & & 914 \\
\hline
\end{tabular}

The motive of affiliation was not always dominant in Ukrainian school textbooks. According to the results of a intercountry study of children's textbooks in the 1930 s of the XXth century conducted by D. McClelland, the motive of power dominated and low levels of the motive of affiliation were observed in the Soviet children's books of Stalin period: "ruthlessly totalitarian regimes nearly always have been marked by high collective levels of the need for Power and low collective levels of the need for Affiliation. Children's textbooks showed this pattern in Germany in 1925, before the rise of Hitler; in Japan before the rise of the military dictatorship in the 1930s; in Russia during the rule of Joseph Stalin" [2, p. 440]. Thus, depending on the socio-political and economic situation in society, the motive content of school textbooks can vary considerably.

High levels of affiliation motive situations in Ukrainian textbooks (on average $30.3 \%$; the lowest level is in the textbook for the $4^{\text {th }}$ form $(24 \%)$, the highest level is in the textbooks for the $2^{\text {nd }}$ and $3^{\text {rd }}$ forms (about 35\%)) can ha- 
ve a positive impact on the formation of this motive in children, which, in turn, according to D. McClelland, can contribute to the development of civil society in the country. "Cultural groups characterized by a high need for affiliation seem to place greater emphasis on care and respect for other people, as reflected in an absence of marital violence and infanticide, closeness of familial relationships, interests in having children, and prosocial adult behavior... Countries high in the concern for affiliation tend to have lower psychogenic death rates from homicide, suicide... A high collective concern for affiliation potentially moderates the expression of the need for Power, thus protecting individual rights against suppression by the government" [2, p. 439].

Let us analyze the negative motive-trends in school textbooks on literature for primary school. First of all, we would like to point out the low level of representation of the motive of achievement in the textbooks (on average, about $17 \%$; the lowest level is in the textbook for the $3^{\text {rd }}$ form $(14.3 \%)$, the highest one - in the textbooks of the $2^{\text {nd }}$ and $4^{\text {th }}$ form $\left.(18.3 \%)\right)$. Since the motive of achievement is formed at the primary school age (from 6 to 10 years), we can conclude that the Ukrainian school textbooks do not sufficiently contribute to the development of the motive. According to the theory of D. McClelland, this can affect the economic state of the country in the future, since "nations whose children's stories score higher in the need for Achievement tend to grow more rapidly economically..., and economic growth were greater after historical periods when the need for Achievement levels were high in popular literature" [2, p. 603].

A quite low level of representation of the motive of self-expression in school textbooks on literature is observed (on average, 3.7\%; from 8 to $11 \mathrm{mo}-$ tives in different textbooks for the $2^{\text {nd- }} 5^{\text {th }}$ forms). If we accept D. McClelland's thesis that changes in the motivational sphere precede objective changes in the social and economic life of society, we can assume that since Ukrainian school textbooks give little attention to the formation and development of the motive of self-expression of children, this will not contribute to postmodernization of values in Ukraine, which implies "a turn to values of self-expression". We would like to stress the fact of low popularity of the motive of selfexpression both in children's textbooks on literature (3.7\%) and in Ukrainian society as a whole (according to the results of the European Values Study conducted in 2008-2010 in 43 European countries using the method of R. Inglehart, only $1 \%$ of Ukrainians are postmodernists (for whom the values of initiative autonomy and self-expression are important [20, p. 18]).

Another negative motive-tendency in Ukrainian school textbooks on literature for primary school is a rather high percentage of motive-situations of 
refusal of affiliation (on average, 15.6\%; the lowest level - in the textbook for the $2^{\text {nd }}$ form $(9.1 \%)$, the highest one - in the textbook for the $4^{\text {th }}$ form $(21.2 \%))$, in which literature characters refuse to interact with other people and avoid the relations of friendship, love, help, participation; they demonstrate contempt, hatred, envy, deception, manipulation of other people (or personified animals, plants, characters from tales) instead. In this regard, we especially can mark the textbook for the $4^{\text {th }}$ form [19], in which the number of motive-situations of refusal of affiliation (44 situations, $21.2 \%$ ) is only slightly inferior to the number of situations of affiliation (50 situations, $24 \%$ ), while in other textbooks affiliation is found 1.5-4 times more often than the refusal of affiliation (the best situation is found in the textbook for the $2^{\text {nd }}$ form, in which 81 contexts of affiliation $(35.2 \%)$ and 21 contexts of refusal of affiliation (9.1\%) were found).

The most alarming is the situation with the power motive: in school textbooks the contexts for using negative motive of power (manifested in acts of violence, humiliation, tyranny, authoritarianism) are twice more often compared to the contexts of using a positive motive of power (10.5\% versus $5.1 \%)$. It can be assumed that frequent use of negative motive of power in textbooks on literature can indirectly affect the situation when the authoritarian models of power becomes more popular among children (and later, youth) than nonauthoritarian ones, since it is just at primary school age the basic motives of behavior are "laid" in the psyche of children.

We also found out that in school textbooks the motive-situations of avoidance of failure (or failure itself) are reproduced quite often; they are repeated somewhat more often than the motive-situations of achievement $(18 \%$ versus $16.8 \%$ ), which indirectly can influence the formation of passive life attitudes and fear of failure in primary school children.

\section{Discussion}

As a result of the study, a segmented picture of motivational dispositions of textbooks has been revealed. At the same time it is difficult to conclude how strong the influence of school literature on the formation of behavioral motives of children is. For example, if reading of textbooks at school lessons is accompanied by a critical analysis of situations of non-achievement, passivity, aggressiveness of literature characters in communication practices [22], it will be able to form a kind of children's immunity against a-social behavioral practices. Conversely, if one does not critically evaluate the content of the text in class, the probability of unconscious adoption of behavior patterns transmitted through textbooks is high. In the future, to obtain more accurate 
results, it is necessary to supplement the motivational content analysis of textbooks with psychological testing of pupils of different forms of primary school to identify the basic behavioral motives, and then compare the results of testing and content analysis. A complex study of the problem of formation of basic motives for behavior in children will also require studying the style of teaching of primary school tutors as well as the nature of up-bringing in families (through interviews with teachers and parents). Teachers and parents can develop achievement, affiliation, desire for self-expression in children and, thereby, neutralize the impact of negative motivational patterns in school literature.

\section{Conclusions}

As a result of the motivational content analysis of the Ukrainian textbooks on literature for the $2^{\text {nd }}-5^{\text {th }}$ forms, several motive tendencies have been revealed.

First, the motive of affiliation (on average, 30.3\%) is the basic motive that is most often reproduced in the discursive space of educational literature. Meanwhile, a rather high percentage of motive-situations of refusal of affiliation has been found in Ukrainian textbooks (on average, 15.6\%).

Second, it has been revealed that in school textbooks the motive-situations of avoidance of failure (or failure itself) are reproduced quite often, which are repeated more often than the motive-situations of achievement (18\% versus $16.8 \%$ ); this can indirectly influence the formation of passive life attitudes at primary school children.

Third, there is a very low level of representation of the self-expression motive in school textbooks (on average, 3.7\%), which may negatively affect the process of postmodernization of values in Ukraine, which implies a "turn to values of self-expression".

Fourth, it has been found that in school textbooks the contexts of using the negative motive of power occur twice as often as the contexts of using a positive motive of power (10.5\% versus $5.1 \%$, which can lead to wide-spreading authoritarian behavior patterns among children.

\section{References}

1. Neuman W. Social research methods: Qualitative and quantitative approaches. Edinburgh Gate: Pearson Education Limited; 2014.

2. McClelland D. Human motivation. Cambridge University Press; 1985.

3. Bowles S. \& Gintis H. Schooling in Capitalist America Revisited. Sociology of Education. 2002; 75(1): 1-18. 
4. Atay M. \& Danju, I. Analysis of $1^{\text {st }}$ grade and $5^{\text {th }}$ grade textbooks and primary school student's views about personal traits in gender role in society. Procedia - Social and Behavioral Sciences [Internet]. 2012 [cited 2017 Sept 25]; 47: 6473. Available from: https://doi.org/10.1016/j.sbspro.2012.06.614

5. Damigella D. \& Licciardello O. Stereotypes and prejudices at school: A study on primary school reading books. Procedia - Social and Behavioral Sciences [Internet]. 2014 [cited 2017 Sept 25]; 127: 209-213. Available from: http:// doi: 10.1016/j.sbspro.2014.03.242

6. Kolosova E. A. Gender and professional socialization in textbooks for primary and preparatory classes in 2000s. Problemy sovremennogo obrazovanija = Problems of Modern Education. 2014; 4: 219-223. (In Russ.)

7. Korneeva E. \& Korotaeva A. Content of teaching materials as a means of constructing gender identity of junior schoolchildren. Jaroslavskij pedagogicheskij vestnik = Yaroslavl Pedagogical Journal. 2015; 1 (II): 106-110. (In Russ.)

8. Sovič A. \& Hus V. Gender stereotype analysis of the textbooks for young learners. Procedia - Social and Behavioral Sciences [Internet]. 2015 [cited 2017 Sept 25]; 186: 495-501. Available from: http://doi:10.1016/j.sbspro.2015.04.080

9. Agha N., Kazim Syed G. \& Ali Mirani D. Exploring the representation of gender and identity: patriarchal and citizenship perspectives from the primary level Sindhi textbooks in Pakistan. Women's Studies International Forum [Internet]. 2018 [cited 2017 Dec 18]; 66: 17-24. Available from: https://doi.org/ 10.1016/j.wsif.2017.11.009

10. Abbas M. \& Khurshid F. Motivational techniques and learners 'academic achievement' at primary level. Global Journal of Human Social Science. Linguistics \& Education. 2013; 13 (3): 15-24.

11. Salani E. \& Maphane E. Botswana primary school teachers' motivational strategies beliefs about Mathematics classroom instructional practices. International Journal of Humanities Social Sciences and Education. 2014; 1 (11): 217-227.

12. Saeed S. \& Zyngier D. How motivation influences student engagement: A qualitative case study. Journal of Education and Learning [Internet]. 2012 [cited 2017 Sept 25]; 1 (2): 252-267. Available from: http://dx.doi.org/ 10.5539/jel.v1n2p252

13. Poledñová I., Stránská Z. \& Niedobová H. Achievement motivation of secondary school students in relation to their social position in the class. Problems of Psychology in the 21st Century. 2014; 8 (1): 61-70.

14. Okolskaya L. A. Labor values and norms in the content of textbooks for primary school: Today and 20 years ago. Voprosy obrazovanija = Education Issues. 2007; 2: 68-85. (In Russ.)

15. Shahmohammadi N. Content analysis of elementary science text books based on the achievement motivation constructs. Procedia - Social and Behavioral Sciences [Internet]. 2013 [cited 2017 Sept 25]; 84: 426-430. Available from: http:// doi.org/10.1016/j.sbspro.2013.06.579

16. Avramenko O. Ukraïns'ka literatura: pidruch. dlja $5 \mathrm{kl}$. zagal'noosvitn. navch. Zakl = Ukrainian literature: textbook for the 5th grade of a comprehensive educational institution. Kyiv, Ukraine: Publishing House Gramota; 2013. (In Ukrain.) 
17. Naumenko V. Literaturne chitannja: ukr. mova dlja zagal'no - osvit. navch. zakl. $\mathrm{z}$ navchannjam ukr. movoju: pidruch. dlja 2 -go $\mathrm{kl}$. = Literature readers: Ukrainian language for primary school with teaching in Ukrainian: textbook for 2nd grade. Kyiv, Ukraine: Publishing House Geneza; 2012. (In Ukrain.)

18. Savchenko O. Literaturne chitannja. Ukraïns'ka mova. 3 klas: pidruch. dlja zagal'no-osvit. navch. zakl = Literature readers: Ukrainian language. 3rd grade. The textbook for primary schools. Kyiv, Ukraine: Publishing House "Osvita"; 2013. (In Ukrain.)

19. Savchenko O. Literaturne chitannja. Ukraïns'ka mova. 4 klas: pidruch. dlja zagal'no-osvit. navch. zakl = Literature readers: Ukrainian language. 4rd grade. The textbook for primary schools. Kyiv, Ukraine: Publishing House "Osvita"; 2015. (In Ukrain.)

20. Magun V. \& Rudnev M. Value heterogeneity of the population of European countries: Typology based on R. Inglehart indicators. Bulletin of Public Opinion. Data. Analysis. Discussions. 2012; 3/4: 12-24.

21. Inglehart R. \& Welzel C. Modernization, cultural change, and democracy: The human development sequence. Cambridge University Press; 2005.

22. Bataeva K. Communicative and instrumental models of educational process in modern philosophy and sociology of education. Gumanitarnyj Chasopys = Humanitarian Journal. 2016; 3: 5-11.

информация об авторе:

Батаева Екатерина Викторовна - доктор философских наук, доцент, профессор кафедры социологии Харьковского гуманитарного университета "Народная украинская академия", Харьков, Украина. E-mail: bataevaekaterina72@yahoo.com

Статья поступила в редакцию 18.10.2017; принята в печать 13.12.2017. Автор прочитал и одобриц окончательный вариант рукописи.

\section{Information about the author:}

Ekaterina V. Bataeva - Doctor of Philosophical Sciences, Associate Professor, Professor of Department of Sociology, Kharkov Humanitarian University "People Ukrainian Academy”, Kharkov, Ukraine. E-mail: bataevaekaterina72@yahoo.com

Received 13.12.2017; accepted for publication 13.12.2017.

The author has read and approved the final manuscript. 